\title{
The feminism and gender violence of international relations theory
}

\author{
LI ZHI \\ Macau University of Science and Technology ISCR, Macau,999078 \\ Zhuhai Art College, GuangDong Zhuhai,519000,China
}

Keywords: international relations; feminism; gender violence

Abstract: during the process of forming traditional western international relations theory, there has been a long time that feminism was neglected, undervalued and excluded from the world of politics. And it was even at the edge of discipline. The main research areas are mostly about wars, conflicts, peace, international laws, diplomatic activity and global trade, etc. Since late 1980, the research of international relations theory gradually became the world's political practice from the perspective of feminism. It is a kind of new research orientation and strength, as international political views give criticism of the biased sex, and proposed a challenge to the ontology and epistemology of traditional international relationship and made the sustainable development of the feminist in the field of international relations.

\section{The origins of feminism-two trends}

"The European enlightenment bewteen the 17th and 18th century was the origins of the women's movement" ${ }^{(1)}$. Its ideas inspired more and more women and they gradually began to wake up. Some examples include: If such as the creation in 1814, the French lady's salon which depicted the social celebrities in 1755 when women gathered together holding salons and discussing their views of the society and mainstream theories with philosophers, scientists, and intellectuals; the guided document in the first wave of women's movement, namely, the declaration of power and opinion was approved in July, 1848, at the village of Seneca falls, New York where the first convention of women's rights was held. The declaration pointed out that all men and women were born to be equal. The creator gave him or her certain inalienable rights, including life, liberty and

\footnotetext{
${ }^{\circledR}$ Huang Liping: A Review of the Feminist Theory of International Relations, Changsha: Hunan Normal University, 2011, p19.
} 
the pursuit of happiness. ${ }^{2}$ Therefore, it declares that the equality between men and women should be doubted and could not be ignored.

Lots of women leaded groups and organizations appeared during the First World War. The Germany women's federations (1865), the French feminist communion (1882), the United States women's election party (1890), and the international union of women's election (1904) were the most influential among others. ${ }^{3}$ With the emergence of these women's organizations, the goal and direction of women's movement became clearer, and the thought of organizing women's activity was more mature female activity. Women had made great progress in the areas of civil rights, education, employment rights and political rights as well as fighting for equality and freedom.

After the First World War, women had made remarkable achievements in the struggle for voting privileges. Many women in western countries gradually won the right to vote. In 1894, women in New Zealand won the right to vote. This event not only made great significance, but also had extensive influence, became it was the first country that women could participate in elections. While at the same time, this event also inspired other countries' women striving for the right to vote. From 1902 to 1917, women in Austria, Finland and Norway obtained the right to vote respectively.

This research argues that the first thought of feminism thoughts was generated by the end of the 19th century and early 20th century. ${ }^{(4)}$ Feminism characterized in the pursuit of equal political rights of women and men, and focusing on women's voting rights, legal rights and political rights. The main difference of the Second World War with other wars is:"it is women's war" ${ }^{(5)}$. This opinion is argued by America's ambassador in London based on the extent of the British women's input into the war. Women are affected by the World War II in some countries. The United States, Britain, the Soviet Union and China's women have joined in the military industry of the Second World War. With the end of the Second World War, the return of men made women under the plight of unemployment, as government's policy focused providing jobs for men, toughly forcing women to go back to their traditional roles. At the same time, the American black liberation movement inspired many American women's rejection. Because of the contradictory deposition between man and women during the World War II, the government's policy greatly made women discontent and

\footnotetext{
(2) Eleanor Flexner. Century of struggle:The Woman Rights Movement in the United States, Cambridge:Harvard University Press, 1975,p.76.

${ }^{3}$ Zhou Zhaoxue: Feminist Theory of International Relations Research, Taipei: Kyushu Island Press, 2010, p 24.

${ }^{(4)}$ Li Yingtao,Hu Chuanrong: Feminist International Relations, Hangzhou: Zhejiang People's Publishing House, 2006, p19.

${ }^{(5)}$ Jerry Bentley, Herbert Ziegler, Wei Fenglian, Zhang Shuo, Bai Yuguang: New Global History, Beijing: Peking
} 
indignation.

"The second rise of feminism started between $1960 \mathrm{~s}$ and the $1970 \mathrm{~s} "{ }^{\circ}$ In this round of thought, feminism began to rethink the traditional prejudice that existed in the theory and practice of international relations, revealing and criticizing gender inequality in international relations, particularly focusing on the women in the third world countries, their social status, the rights of representation and the unequal treatment.

Eliminating the differences between men and women was the main thought of the feminist political movement after the second time after the World War II. In 1949, the famous French feminist, Simone DE Beauvoir, one of the founders of feminism movement, published "the second sex (Le Deuxieme Sexe), shocking the world, which marked the arrival of the second thought, and established her pioneer status in the study of Western feminism. Beyond the analysis of the physiology sex by nature, the other female aspects of women are all the result of the society, which was the same as for men. Additionally, Simone DE Beauvoir thought that the social, historical, political, and cultural constraints were the main interferes that hindered the free equal rights for women, rather than the natural physical characteristics. In 1966, Betty Friedan founded the national women's organizations; In 1974, the united union women was created in Chicago; In 1975, "united front" black women formed in Detroit; In 1977, the first meeting for French women meeting was held which passed the 25 items about women's equal rights; in 1975, 1980 and 1985, the United Nations held three world women’s conferences in Mexico City, Copenhagen, and Nairobi; In 1995, the fourth world conference on women was held in Beijing, China.

The second thought of feminism was not only large, but also well organized and legitimated. It had formed academic research issues of feminist international relations theory among the female scholars, namely, "women's studies", which was also called as gender studies. These fully shows that the global women began to unite, to make contributions in participating in the practice of international relations, and even to play a more important role in the international community.

\section{Feminist theories in international relationship studies}

There were several theoretical definitions about feminism through the analysis about studies of feminist theory, such as liberal feminism, socialist feminism, and radical feminism, and so on. Then, these terms have different meanings and it was also different from the opinion from the 1970s and

(6) Li Yingtao,Hu Chuanrong: Feminist International Relations, Hangzhou: Zhejiang People's Publishing House, 2006, p19. 
1980s , the best way is to refer to others' ideas, and then summarized and "labeled" it. It was found that these so-called theory viewpoints and research streams could be divided artificially. Most scholars divided the feminist international relations theories into three major categories: the feminist empiricism, feminist standpoint theory and postmodern feminism, according to the standard of classification by Sandra Harding. The feminist international relations theory could also be divided into liberal feminism, radical feminism, Marxism and postmodern feminism, etc from the perspective of the political stance. Their opinions was varied, and even conflicted in eliminating the gender discrimination in the field of international relations. ${ }^{(7)}$ Different academic groups criticized and complemented with each other in the content.

The following is a reviewing about the theories of different research streams:

\begin{tabular}{|c|c|c|c|}
\hline $\begin{array}{c}\text { Theoretical } \\
\text { streams }\end{array}$ & epistemology & Main idea & $\begin{array}{c}\text { Representative } \\
\text { scholars and their } \\
\text { works }\end{array}$ \\
\hline $\begin{array}{l}\text { The } \\
\text { international } \\
\text { relation } \\
\text { theory of } \\
\text { liberal } \\
\text { feminism }\end{array}$ & $\begin{array}{l}\text { The basis was the } \\
\text { Feminist } \\
\text { Empiricism }\end{array}$ & $\begin{array}{l}\text { Liberal feminism is the starting point of } \\
\text { feminist schools. It emphases on women's } \\
\text { pursuit of equal rights. To change women’s } \\
\text { traditional concepts among countries; Equally } \\
\text { open to women. Men and women should have } \\
\text { the basic rights, equal legality and political } \\
\text { rights in international relations. }\end{array}$ & $\begin{array}{l}\text { Marry Wollstonecraft } \\
\text { 《Women 's Defense》 } \\
\text { Betty Friedan《The secret } \\
\text { of women》 }\end{array}$ \\
\hline $\begin{array}{l}\text { The } \\
\text { internationa } \\
\text { l theory of } \\
\text { radical } \\
\text { feminism }\end{array}$ & $\begin{array}{l}\text { The basis was } \\
\text { the Feminist } \\
\text { Stand-point) }\end{array}$ & $\begin{array}{l}\text { Radical feminism argue that patriarchy } \\
\text { (patriarchy) is the root of women's } \\
\text { oppression; Studying on women to } \\
\text { participate in the activities of } \\
\text { international practice, the contributions } \\
\text { and the superiority of femininity, } \\
\text { including male oppression of women, } \\
\text { fundamentally change the male } \\
\text { centered traditional international } \\
\text { relations theory system. }\end{array}$ & $\begin{array}{l}\text { Kate Millett 《Sexual } \\
\text { Politics》, Shulamith } \\
\text { Firestone 《Dialectics } \\
\text { of Nature》 }\end{array}$ \\
\hline $\begin{array}{l}\text { The } \\
\text { Internationa } \\
\text { l theory of } \\
\text { Marxist } \\
\text { feminism }\end{array}$ & Marxism & $\begin{array}{l}\text { In Marxist feminism emphasizes the } \\
\text { inequality between men and women, } \\
\text { women's oppression is the political, } \\
\text { social and economic system of } \\
\text { capitalism, overthrow capitalism of the } \\
\text { international system is to obtain the } \\
\text { necessary way to equality between men } \\
\text { and women, gender discrimination is } \\
\text { the manifestation of social inequality. }\end{array}$ & $\begin{array}{l}\text { Karl Heinrich Marx } \\
\text { 《 Family, Private } \\
\text { Ownership and the } \\
\text { origin of the State》 }\end{array}$ \\
\hline
\end{tabular}

${ }^{(7)}$ Hu Chuanrong: Feminism and International Relations - Gender Analysis of Rights, War and Development, Shanghai: World Knowledge Publishing House, 2010, p42. 


\begin{tabular}{|c|c|c|c|}
\hline $\begin{array}{l}\text { The } \\
\text { international } \\
\text { relations } \\
\text { theory of } \\
\text { socialist } \\
\text { feminist }\end{array}$ & $\begin{array}{l}\text { The feminist } \\
\text { standpoint of } \\
\text { Marxism }\end{array}$ & $\begin{array}{l}\text { "Socialist feminism aims to search for the } \\
\text { reasons about why women were oppressed in } \\
\text { the binary system of capitalism". }{ }^{\circledR} \text { The unequal } \\
\text { status of women is caused by the system. The } \\
\text { main reasons include: capitalist patriarchy, } \\
\text { class antagonism and gender discrimination/ }\end{array}$ & $\begin{array}{l}\text { Gayle Rubin 《Towards } \\
\text { Women 's } \\
\text { Anthropology》, Juliet } \\
\text { Mitchell 《Women: the } \\
\text { longest revolution》 }\end{array}$ \\
\hline $\begin{array}{l}\text { The } \\
\text { international } \\
\text { theory of } \\
\text { post-modern } \\
\text { feminism }\end{array}$ & $\begin{array}{l}\text { Post-modern } \\
\text { feminism }\end{array}$ & $\begin{array}{l}\text { Eliminating the current concept of gender, } \\
\text { deconstruction past relationship theory; } \\
\text { stressing the construction of social culture and } \\
\text { the difference between women; paying } \\
\text { attention to the different subject of negotiation } \\
\text { dialogue; valuing the role of listening and } \\
\text { empathetic relationship. }\end{array}$ & $\begin{array}{l}\text { Julia Kristeva、 Helene } \\
\text { Cixous、(Luce Irigaray). }\end{array}$ \\
\hline $\begin{array}{l}\text { The Third } \\
\text { World/The } \\
\text { international } \\
\text { theory of } \\
\text { post-colonial } \\
\text { feminism }\end{array}$ & $\begin{array}{l}\text { Post-colonial } \\
\text { feminism }\end{array}$ & $\begin{array}{l}\text { Post-colonial feminism is a kind of opposition } \\
\text { to class, race, national and social gender } \\
\text { hegemony of the struggle; Criticism of the } \\
\text { third world women image of the western } \\
\text { centralism tendency, express the concerns of } \\
\text { the third world women, and put forward the } \\
\text { concept of Colonization. }\end{array}$ & $\begin{array}{l}\text { Chandra T.Mohanty、 } \\
\text { Gayatri Chakravorty } \\
\text { Spivak. }\end{array}$ \\
\hline
\end{tabular}

III. The triple system of gender violence

International relationship is not a gender neutral discipline, but it has very close connection with social gender. Feminism is diverse with a variety of positions and factions. However, there are no clear boundaries among those factions. One of the founders of Peace studies, Johan Gahung, the famous scholar from Norway proposed the violence triangle theory. He suggested that structural violence, direct violence and cultural violence were interrelated with the causal system of violence, while social gender was very tight. His opinion caused the attention of the feminism research community. ${ }^{9}$ The triple violence system and the comprehensive analytic violence are all based on the position of Marxist feminist theory, belonging to the feminist international relations theory system of socialism.

Table: Gender and triple violence system

\begin{tabular}{clll}
\hline & Structural Violence & Direct Violence & Cultural violence \\
\hline & $\begin{array}{l}\text { Political, Economic, Cultural } \\
\text { andResource Inequalities }\end{array}$ & War and Conflict & Cultural and traditional \\
\cline { 2 - 3 } International Order & Country and Region & The War Between & practices \\
\cline { 2 - 3 } Inequality & Development Degree & Nations; Conflict of & Men's Superiority to Women \\
& Difference; & Ethnic; & Favor Boys Over Girls \\
\hline
\end{tabular}

${ }^{8}$ Christine Sylvester, Yu Xiaofeng、Pan Yihe、Guo Xiajuan: 《Feminism and Post - modern International Relations》, Hangzhou: Zhejiang People's Publishing House, 2003, p84.

(9) Johan Galtung, "Violence, Peace and Peace Research”, Journal of Peace Research, v01. 6, 1969, P.170 173. 


\begin{tabular}{|c|c|c|c|}
\hline & $\begin{array}{l}\text { Country big or small, } \\
\text { Strength or Weakness } \\
\text { Difference; } \\
\text { Cultural Difference; }\end{array}$ & $\begin{array}{l}\text { Conflict of } \\
\text { Civilizations, } \\
\text { War, rape; } \\
\text { Transnational women } \\
\text { trafficking forced } \\
\text { prostitution; }\end{array}$ & $\begin{array}{l}\text { Separation Between Men } \\
\text { and Women; } \\
\text { Women 's Chastity }\end{array}$ \\
\hline $\begin{array}{l}\text { Domestic } \\
\text { Inequality }\end{array}$ & $\begin{array}{l}\text { Regional Difference; } \\
\text { Class Difference; } \\
\text { Ethnic Inequality; } \\
\text { Sexism; } \\
\text { Religious Discrimination etc; }\end{array}$ & $\begin{array}{l}\text { Conflict of Ethnic; } \\
\text { Conflict of Class; } \\
\text { Torture; } \\
\text { domestic violence, } \\
\text { women trafficking, } \\
\text { forced prostitution; } \\
\text { Sexual harassment etc; }\end{array}$ & \\
\hline $\begin{array}{l}\text { Individual } \\
\text { Inequality }\end{array}$ & $\begin{array}{l}\text { Sexism; } \\
\text { Racial discrimination, } \\
\text { Level difference etc; }\end{array}$ & $\begin{array}{l}\text { Family Violence; Rape } \\
\text { of Women } \\
\text { Forced Prostitution; } \\
\text { Trafficking in Women; } \\
\text { Abortion; } \\
\text { Clitoridectomy; } \\
\text { Kill; } \\
\text { Sexual Harassment; } \\
\text { Abuse of Girls; }\end{array}$ & \\
\hline
\end{tabular}

To sum up, social gender is very closely with gender and triple violence system, and the triple system of violence works interactively from the international, national and individual level, which could cause all kinds of violence and constitute a violent network. From the perspective of social gender violence, triple violence system framework enriched the feminism research field. No matter it was the inequality of international order, or the domestic inequality and personal inequality, trafficking in women is a worldwide problem reflecting the root of violence against women.

\section{The development and practice of feminism in China}

Feminist international relations theory began to enter the field of international relations since 1960s. However, it was not until the late $80 \mathrm{~s}$ of the 20th century the academic status of feminism began to establish in the world. China's feminist international relations research has also made some progress by absorbing the existing results of the western feminist international relations research results as well as combining with the studies on social gender. Facing to the violence against women in the international relationship environment, China actively participates in holding "women's issues", like female migrants, cross-border trafficking, women's oppression in multinational companies, the influence of wars and conflicts to women, exploring the influence of relevant international law from the social gender, taking concrete actions to support the 
development of feminism in China.

First of all, with the influence of the international women's movement, China women's federation actively joined the international women's federation, which was the earliest Chinese women's cross-cultural activity. Besides, China also held some conferences which took feminist international relations as the theme of the meeting. Some examples include such as in October, 2003, Fudan University and the University of Hong Kong jointly organized the international academic seminar named "women and international relations" and, in November, 2003, the Chinese Academy of Social Sciences held an academic seminar named "non-traditional security and China”.

Secondly, the Chinese government has made related policy practice for the protection of women and children. These include: formulating and perfecting the laws and regulations of criminals to women and children; strengthening the international cooperation in the judicial and police work in cracking down on the crime of trafficking in women and the children of violence. The Chinese government has also signed some policing cooperation agreements with the other countries' certain departments, to put crack down on the crime of trafficking in women and the children as the main cooperated areas.

Academically, there has published some monographs and translated books related feminist international relations discussing about the contribution of Western feminist international relations in the world.

Some examples include: western international politics: history and theory authored by Wang Yitao in 1998; the international politics from the social gender perspective by Li Yingtao in 2003; the development of feminist international relations by Li Yingtao and Hu chuan-rong; the feminism, and international relations - rights, wars and the development of social gender analysis by $\mathrm{Hu}$ Chuan-rong in 2010, etc.

\section{Conclusion}

This study explores the development and practice of the feminist international relations theory in the context of China through the analysis of two feminist thoughts and the triple system of gender violence, based on feminism theories of international relations. The main content of this study is embodied in the feminist international relations theory of Marxism, and the relationship between Chinese traditional culture and the feminist international relations theory. In the practice of feminist groups, the Chinese government is willing to actively participate in bilateral exchanges as well as preventing the crime of the abduction and violence of women and children. Existing practice shows 
that the Chinese government wants to work with other countries and regions, international organizations and non-governmental organizations to strengthen cooperation, to resist international women's violence crime. Some other measures include: building the positive image of China's superpower status in the international environment, increasing the international convention on the protection of women and children and the publicity of laws and regulations, promoting the development of peace studies of feminism, to eliminate all forms of violence to women in order to achieve peace and non-violence, to reduce the violence against women, and to provide a good environment for the development of feminism in China in the end. 